\title{
Sodium ascorbate use in bleached teeth
}

\author{
Robson de Sousa Ferreira ${ }^{a}$, Elanno Pádua Albuquerque do Nascimento ${ }^{a}$
}

\begin{abstract}
OBJECTIVE: Tooth bleeching is a routine intervention in dental office, to be effective in removing stains and browning that compromise the aesthetics of smile. Sometimes there is a need of complementing with composite restorations, but for the use of these requires a certain waiting time. Thus, use of antioxidants such as sodium ascorbate increases the bond strength values due to removal of residual oxygen hinder polymerization. This study examined the use of sodium ascorbate as measure to allow for immediate adhesive restorations after bleaching procedures in vital teeth.

METHODS: For that, they consulted national and international studies published between 1973 and 2015 available in Scielo, VHL and PubMed platforms.

CONCLUSION: It can be concluded that sodium ascorbate has clinical relevance, but its use should be performed with caution, necessitating further investigation. The fact that in some studies its application introduced effective can not be attributed to factors inherent in the methodology.
\end{abstract}

Key words: Aesthetics; Antioxidants; Tooth bleaching

\section{Uso do ascorbato de sódio em dentes clareados}

\section{RESUMO}

INTRODUÇÃO: O clareamento dentário é uma intervenção rotineira nos consultórios odontológicos, por ser efetivo na remoção de manchas e escurecimento que comprometem a estética do sorriso. Por vezes há a necessidade de sua complementação com restaurações de resina composta, porém para o emprego destas requer certo tempo de espera. Assim, o uso de antioxidantes como o ascorbato de sódio aumenta os valores de resistência de união devido à remoção do oxigênio residual que atrapalharia sua polimerização. Este estudo verificou o emprego do ascorbato de sódio como medida para permitir a realização de restaurações adesivas imediatas após procedimentos clareadores em dentes vitais

METODOLOGIA: Para tanto, foram consultados trabalhos nacionais e internacionais publicados entre os anos de 1973 e 2015 nos idiomas português e inglês disponíveis nas plataformas Scielo, BVS e PubMed.

CONCLUSÃO: Pode-se concluir que o ascorbato de sódio apresenta relevância clínica, mas seu emprego deve ser executado com cautela, necessitando-se de mais pesquisas. O fato de que em alguns estudos sua aplicação não se apresentou efetiva pode ser atribuído a fatores inerentes à metodologia empregada.

Palavras-chave: Antioxidantes; Clareamento dentário; Estética

a School of Dentistry, Universidade Federal do Piauí, Teresina, Brazil 


\section{INTRODUCTION}

Among the aesthetic treatments currently available, it can highlight the tooth bleaching, routine intervention in dental office [1]. It is important to remember that sometimes there is a need to complement the bleaching treatment with composite restorations, since on the contrary dental structures, composites are not bleached and need to be replaced. Knowing this, it is necessary to remember that the use of adhesive restorations after tooth bleaching requires a certain waiting time because the bleaching products commit their bond resistance [2].

The waiting 24 hours to 3 weeks for the manufacture of adhesive restorations in bleached teeth has been reported in the literature to recover the strength lost adhesion. However, this waiting period may not be feasible in situations where the aesthetic requirement is immediate [3]. From this, several methods have been proposed to overcome these adversities [4].

It has been observed that among of all the methods, the use of antioxidants has improved bond strength values, while others have shown conflicting in recovering such amounts. Among the antioxidants available, there is sodium ascorbate (SA) which, through its salts, has the ability to scavenge free radicals of dental substrate. However, it is important to note that, even for this agent, the complete reversal of the loss of adhesion is not possible $[3,5]$.

\section{OBJECTIVES}

Through literature review:

- Check the effectiveness of SA as a measure to allow for immediate adhesive restorations after bleaching procedures in vital teeth;

- Observe if AS has relevance to justify its use clinically.

\section{LITERATURE REVIEW}

\section{Tooth bleaching}

The peroxides are oxididants agents of low molecular weight, in contact with the tooth structure, they are easily diffused to the inside of the dentinal canaliculi, where the hydrogen peroxide (HP) decomposes into water and oxygen, Carbamide Peroxide (CP), carbon dioxide and ammonia. This redox process promotes the bleaching effect, in which the long molecular carbon chain pigment (dark) will be broken into short carbon chains [6].

By applying a HP or CP gel based on discolored teeth, the bleaching properties of the art can be verified. Vital teeth bleaching can be performed by two techniques: office and supervised home technique [7]. It is observed in the literature that both techniques have similar efficiency in enamel [8], but have diferences in dentin, and noted that the home bleaching is most effective in deep tissues [9].

It is important to remember that HP is the active compound of the bleaching action, even when used in form of CP. So if the dentist seeks quick action of the bleaching agent, use
$\mathrm{PH}$ bleaching and when it chooses to $\mathrm{CP}$, it prioritizes not the speed in bleaching, but a higher efficiency in bleaching deeper structures, such as dentin, since the concentration of the $\mathrm{pH}$ is lower, but continuous [9].

After HP dissociation in reactive free radicals which initiates the mechanism of tooth bleaching. These radicals react with substances that darken the teeth, existing dentin and the intraluminal fluid through a redox process occurs fragmentation of the parent molecule by converting dark in clear substances. After these redox reactions, obtains the products $\mathrm{CO}_{2}$ and $\mathrm{H}_{2} \mathrm{O}$, by changing the color of the tooth for clearer tone [10].

The action of peroxide, when used in home tecnique, will be gradually. With the increased time of use, agents penetrate deeper into the enamel and thus grant its clearance. It is important to remember that, although the degree of bleaching is dependent on the peroxide concentration used and application time, there is usually a limit observable in which additional applications do not produce any more noticeable bleaching, reaching saturation [11].

\section{Interference of residual oxygen in the adhesion}

The adhesion process to the tooth structure is based on enamel and dentin etching aimed at removing its structural organic content, thus forming irregularities favor the penetration of resin monomers [12].

The completion of the previous acid etching promotes the removal of the smear layer and smear plugs, surface demineralization of dentin and exposure of collagen fibrils. From this, there is the penetration of the bond system in demineralized structure and dentinal tubules, causing the formation of the hybrid layer and tags [13]. The formation of this layer allows the return of the resistance lost by etching and protects against the occurrence of infiltrations [14]. However, this whole process can be compromised if performed immediately after bleaching, so watching it is commited bond strength [15], higher occurrence of infiltrations [16] and even decrease in the size of the tags obtained in substrate [17].

It is known that during the bleaching process peridroxil free radicals, nascent oxygen and hydroxyl penetrate the dental tissue to react with the substances responsible for browning. As adhesive restorative procedures require the formation of the hybrid layer of enamel and dentin, the contact of the monomers with free radicals remaining prevent or hinder the polymerization reaction, compromising the clinical performance of restauration [18].

The decrease of adhesive bonding can lead to early loss of restorations by problems such as decrease in bond strength values found by shear testing and the presence of microleakage and low adhesivness [19]. So then, it is recommended not to run restorations after the bleaching [20].

Despite the belief that the residual oxygen to be responsible for decreasing the bond strength, we should not forget that some percentage effect on the enamel also have some mechanical interference, such as micro-porosity in 
the enamel prisms and interprismatic region that can serve as tension points and cause premature failure in in vitro tests $[12,21]$.

It is also known that the surface of bleached teeth can suffer remineralization after bleaching action through the saliva, which has antioxidant action, but its neutralizing effect is slow. Thus, for the bleached tooth receive new adhesive restoration and obtain a satisfactory result in the accession process required a wait 7-21 days so that the residual peroxide is completely decomposed $[5,6]$.

Since this time interval can be too long for some patients, elimination of free radicals would allow an immediate aesthetic rehabilitation. This mechanism allows restoring the adhesiveness of the composites on the bleached enamel, which has been observed in studies using, for example, SA $10 \%$, because the substance has the capacity to eliminate remaining free radicals $[15,16,22]$.

\section{Mechanisms for immediate adhesion after-bleaching}

The waiting time for the execution of restorations after bleaching may compromise clinical outcome desired. Thus, alternatives such as the use of antioxidant enzymes that carry out the role to accelerate the redox process of the remaining peroxide have been proposed [23]. Other products, such as SA are also being used for the same purpose, thus enabling the immediate exchange of adhesive restorations [6].

Aiming to minimize the adhesive problems arising from the use of peroxides, many authors have indicated the use of neutralizing agents. Some believe that this technique has the advantage of achieving the end result of the proposed treatment in short time without requiring the rest period, or in emergency situations where the teeth are undergoing the bleaching treatment [5].

The most studied neutralizing are the antioxidants such as catalase, ethanol, acetone, ascorbic acid and sodium bicarbonate, the latter has a neutralizing effect when acting on soft tissue, whereas in enamel and dentin its action is not significant, without participation in the restructuring and adhesive process [5].

Pretreatment of dentin and enamel with neutralizing antioxidants provides the adhesive restorations satisfactory bond strength, thus enabling the restorative treatment immediately after bleaching [6,22]. However, it is noteworthy that although the bond strength is satisfactory, this is lower than that of a tooth in natural state [5].

Several other measures have been reported in the literature aiming to make possible the production of instant adhesive restorations in bleached teeth, as the surface treatment with substances such as butylhydroxyanisole16, catalase and etanol [5], finding no significant values increase in bond strength immediately after implementation [21].

The use of bonds with organic solvents and nanoparticles have also been studied in an attempt to improve the bond strength on bleached teeth. Thus, bonds with solvent base and water nanoparticles [22], water alcohol and ketonebased [25], and self-etching and conventional bond systems [24,25] were evaluated and found low values of bond strength in all studies.

The Fluoride use in the composition of bleaching agent was also studied order to increase the bond strength after bleaching, which was not found in the research conducted [26].

Among all the mechanisms for post-bleaching immediate adhesion, application of antioxidants has been the most studied. Use of SA for example was discussed, where there was slight increase in bond strength values [16] and equivocal values in microshear [15].

Other research sought to evaluate the bond strength through the application of other antioxidants such as catalase, ethanol and water, discovering unfavorable result [27]. The performance of ozone layer and a redox liquid consisting of xylitol, fluoride and water after application of HP 35\% was evaluated without finding significant results in bond strength or microshear [28].

The $\alpha$-tocopherol is the most active component of vitamin $\mathrm{E}$, and was also used as an antioxidant agent in bleached teeth, and sometimes presented similar results to SA. In the human body, it is a powerful antioxidant in the lipid phase, working to combat diseases such as cancer, atherosclerosis, cataracts, arthritis, senile dementia and respiratory diseases induced by pollutants. However, few studies with the substance have been reported, requiring greater focus in this regard [29].

\section{Sodium ascorbate}

The presence of oxygen radicals is responsible for the decrease of the bond strength in newly bleached teeth and the use of SA has been an alternative to overcome this fator [30,31].

The application of SA should be performed after bleaching sessions or the end of the bleaching action [2]. The product can be applied in a gel or solution, both of which have performed $[32,33]$. Thereafter, the tooth surface must be washed with water for removal of the product. It should also be out, with regard to the product application time, this has shown differences in the literature, being appointed as effective 10 minutes applications [30,34,37] to 1 minute [30].

The beneficial role in restoring the bond strength was also evident where that by treating the surfaces previously observed with SA results in shear strength similar to when postponing the restoration in a week [15,32]. It is known also that the SA enables acceleration of removal of residual oxygen radicals in dentin and enamel in teeth recently bleached, improving the sealing ability of restorations [6].

The effectiveness of SA was compared with other antioxidants in some studies where it was observed that the treatment with solution $\alpha$-tocopherol $10 \%$ was the only agent effective to reverse the oxidizing effect of the bleaching enamel [35].

Analyzing the influence of SA $10 \%$ in the formation of tags and hybrid layer in dentin in teeth after bleaching, it was concluded that dental bleaching with $\mathrm{CP}$ or HP affect the formation of resinous tags and hybrid layer, while the use of SA increases the length of this structure [17]. 
Once highlighted the effectiveness of SA to retrieve the bond strength was observed behavior when associated to different types of bond systems, where it was found that the best performance of the antioxidant occurred in association with conventional 3 steps bond system, but not the type of solvent present in the formulation did not exercise interference in its action [22,25].

Evaluating the effectiveness of short-term application of SA 35\% to reverse the bleaching effects with HP 35\% on the bond strength, it was found that in the short term, is not effective clinically in reversing the effects of bleaching on bond strength [31].

It was evident in study the antioxidant performance not only AS $10 \%$, but the rosemary and Pedicularis extract. It was found that they were effective in reversing the shear strength immediately after bleaching [3].

The effect of three antioxidants (SA, SA combined with a surfactant, and catalase) in microleakage of composite resin restorations after external tooth bleaching with CP $10 \%$, it was observed that catalase was more effective at increasing bond strength, while the postponement of the restoration or treatment with SA were not able to effectively reduce infiltration [36].

\section{DISCUSSION}

Treatment with antioxidants was evaluated in studies such as Torres et al. [5], where catalase showed the best performance in the bond strength recovery, overcoming the action of SA and other substances tested. However, none were able to completely remove the residual oxidizing agents. These results were also observed in studies of Kum et al. [27] and Han et al. [36].

The study of Kaya and Türkün [16] not only showed that the bond strength is lost in newly bleached teeth, a fact that corroborates most studies, but also shows the effectiveness of SA in reverse this situation and butylhydroxyanisole's inability to play such function.

The favorable antioxidant action from SA to adhesion was also pointed out by Lai et al. [22], where it was observed that the agent was able to restore adhesion in treated specimens with both water-based (Single Bond, 3M ESPE) as ketone (Prime \& Bond, Dentsply) bond systems.

However, through the work of Korhoushi and Aghelinejad [25], it was found that the effectiveness of SA will depend on the chemical composition of the bond to be used, because of all the bond systems, Optibond FL, Optibond Solo Plus and Optibond All- in-One (Kerr), showed different bond strength values. In this case, it is important that further study involving different brands of bond systems present currently are made in order to have greater understanding on the subject.

Lai et al. [22] showed the loss of bond strength after bleaching and his recovery after the use of SA in teeth treated with Single Bond (3M ESPE) and Prime \& Bond (Dentsply), agreeing with the range of studies Gama et al. [6] and Dabas et al. [37]. Already Güler et al. [34] emphasize that the SA performance will vary according to the composition of the bond system.

Türkün and Kaya [15] found that the resistance values obtained after the AS application are similar to bleached teeth with an interval of one week after bleaching and teeth restored immediately have low bond strength values.

Marson et al. [2] have observed that the use of SA 40\% gel, both in single application or when used daily resulted in similar satisfactory bond strength values, which differs from that found by Hansen et al. [31], who claim that application of SA $35 \%$ in a short time is not effective clinically in reversing the effects of bleaching on the bond strength. Therefore, adhesive procedures should be postponed before bleached teeth. The concentration differences could be one of the causes for the named differences result as well as the methods employed for each study.

Sasaki et al. [35] have reported that solution of $\alpha$-tocopherol $10 \%$ treatment is the only agent effective to reverse the effects of oxidative bleaching in enamel. The authors are based on the Torres et al. [5] findings. They believe that the application time must be an essential factor for the success of antioxidant therapy, and varies depending on the product to be tested. However, in the study of Whang and Shin [29], both tocopherol and the SA showed to be effective.

Toseto [17] found that the dental bleaching with CP or HP affect the formation of tags and hybrid layer, while the SA increases the length of the structure.

Its application time was also analyzed by Dabas et al. [37] where noted that the bond strength values obtained were similar even in different time intervals $(30,60$ and 120 minutes) and different concentrations.

Freire et al. [30] claim that, in an appropriate concentration, SA $10 \%$ facilitates rapid elimination of residual peroxide to two minutes after the bleaching with HP 35\%, while Güler et al. [34] say that the application of this should give for about 10 minutes, time estimated also by Suneetha et al. [3] However, Whang and Shin [29], say one minute would be enough for the agent/s action. Despite the differences, which may be due to the methodology used in each study, all these authors indicate that professionals can carry adhesive procedures after the bleaching procedure provided the correct protocol application to be followed. This fact only confirms the need to conduct more studies on the subject to ensure more foundation, and thus facilitate their establishment on a day-to-day clinical.

\section{CONCLUSION}

About the application of SA, it can be inferred:

- It has performed effectively at different concentrations, forms of presentation and application time in most of the studies analyzed;

- It has clinical relevance, but its use should be performed with caution, necessitating further studies on their performance due to the different types of available bond systems currently. 


\section{REFERENCES}

1. Borges GA, Pereira GA, Martinelli J, Oliveira WJ. A influência do clareamento dental na resistência de união na interface resina-esmalte. Robrac. 2006;15(40).

2. Marson FC, Sensi LC, Vieira, LCC, Baratieri LN. Influência do gel de ascorbato de sódio na resistênciaadesiva entre resina composta e esmalte clareado. Revista de Odontologia da UNESP. 2007;36(1): 17-21.

3. Suneetha R, Pavithra S, Thomas J, Swapna Priya Nanga G, Shiromany A, Shivrayan A. An In Vitro Comparative Study of Shear Bond Strength of Composite Resin to Bleached Enamel using Synthetic and Herbal Antioxidants. Journal of International Oral Health. 2014;6(6): 77-81.

4. Barghi N, Godwin JM. Reducing the adverse effect of bleaching on composite-enamel bond. J Esthet Dent. 1994;6(4):157-61. https://doi. org/10.1111/j.1708-8240.1994.tb00852.x

5. Torres CR, Koga AF, Borges AB. The effects of anti oxidant agents as neutralizers of bleaching agents on enamel bond strength. Braz $\mathrm{J}$ Oral Sci. 2006;5(16):971-6.

6. Gama AM, Santos RMN, Pedrosa Guimarães R, Vicente da Silva, $\mathrm{CH}$ Restaurações adesivas em dentes pós-clareados: efeito do ascorbato de sódio na remoção do $\mathrm{O}_{2}$. Revista Odonto Ciência. 2006;21(53).

7. Oliveira PHC, Esteves OM, Cassoni A, Rodrigues JA. Técnicas e agentes antioxidantes utilizados para melhorar a união de restaurações após clareamento dental: uma revisão integrativa. Revista Saúde. 2014; $8(1 / 2)$.

8. Barcessat ARP. Estudo comparativo da cor dental "in vivo" em pacientes submetidos a diferentes técnicas de clareamento [Dissertação]. São Paulo: Faculdade de Odontologia, Universidade de São Paulo, 2007.

9. Dietschi D, Rossier S, Krejci I. In vitro colorimetric evaluation of the efficacy of various bleaching methods and products. Quintessence Int. 2006; 37(7):515-26.

10. Haywood VB, Heymann HO. Nightguard vital bleaching: how safe is it? Quintessence International. 1991;22:515-23.

11. Sung EC, Chan SM, Mito R, Caputo AA. Effect of carbamide peroxide bleaching agent enhanced enamel. J Prosthet Dent. 1999;82:595-9. https://doi.org/10.1016/S0022-3913(99)70060-0

12. De Munck J, van Landuyt K, Peumans M, Poitevin A, Lambrechts $P$, Braem $M$ et al. A critical review of the durability of adhesion to tooth tissue methods and results. J Dent Res. 2005; 84(2):118-32. https://doi. org/10.1177/154405910508400204

13. Nakabayashi N. Hybridization of natural tissues containing collagen with biocompatible materials: adhesion to tooth substrates. In: Tsuruta T, Nakajima A (ed). Multiphase Biomedical Materials. Tokyo: VSP Books, 1989:89-104.

14. Fusayama T. Posterior adhesive composite resin: a historic review. J Prosthet Dent. 1990;64:534-8. https://doi.org/10.1016/0022-3913(90) 90123-T

15. Türkün M, Kaya $A D$. Effect of $10 \%$ sodium ascorbate on the shear bond strength of composite resin to bleached bovine enamel. J Oral Rehabil. 2004;31:1184-91. https://doi.org/10.1111/j.1365-2842.2004.01369.x

16. Kaya AD, Türkün M. Reversal dentin bonding to bleached teeth. Oper Dent. 2003;28:825-9.

17. Toseto RM. Influência de uma substância antioxidante na união de materiais resinosos à dentina após a realização de clareamento [Dissertação]. Araçatuba: Universidade Estadual Paulista "Júlio de Mesquita Filho" - UNESP; 2010

18. Titley DC, Torneck CD, Smith DC, Adilbfar A. Adhesion of composite resin bleached and unbleached bovine enamel. J Dent Res. 1988;12(67):1523-8. https://doi.org/10.1177/00220345880670121601

19. Teixeira EC, Turssi CP, Hara AT, Serra MC. Influence of post-bleaching time intervals on dentin bond strength. Braz Oral Res. 2004; 18(1):75-9. https://doi.org/10.1590/S1806-83242004000100014
20. Silva CLM, Pereira MA, Silva TCFM. Avaliação in vitro da resistência de união adesiva de uma resina composta à dentina após aplicação do peróxido de carbamida a 10\%. JBD j bras dentística \& estética. 2003; 2(7):197-201.

21. Bittencourt BF, Domínguez JA, Gomes OMM, Scholz N. Post-whitening adhesion and time intervals: a topic review. Ver Fac Odontol Univ Antioq. 2013; 24(2):336-46.

22. Lai SC, Tay FR, Cheung GS, Mak YF, Carvalho RM, Wei SH et al. Reversal of compromised bonding in bleached enamel. J Dent Res. 2002; 81(7): 477-81. https://doi.org/10.1177/154405910208100709

23. Rotstein I, Dankner E, Goldman A, Heling I, Stabholz A, Zalkind M. Histochemical analysis of dental hard tissues following bleaching. J Endod. 1996;22(1):23-5. https://doi.org/10.1016/S0099-2399(96)80231-7

24. Moule CA, Angelis F, Kim GH, Le S, Malipatil S, Foo MS, Burrow MF Thomas D. Resin bonding using an all-etch or self-etch adhesive to enamel after carbamide peroxide and/or CPP-ACP treatment. Aust Dent J. 2007;52:133-7. https://doi.org/10.1111/j.1834-7819.2007.tb00478.x

25. Khoroushi M, Aghelinejad S. Effect of postbleaching application of an antioxidant on enamel bond strength of three different adhesives. Med Oral Patol Oral Cir Bucal 2011;16(7):e990-6. https://doi.org/10.4317/ medoral. 17127

26. Chuang SF, Chen HP, Chang CH, Liu JK. Effect of fluoridated carbamide peroxide gels on enamel microtensile bond strength. Eur J Oral Sci 2009; 117(4):435-41. https://doi.org/10.1111/j.1600-0722.2009.00645.x

27. Kum KY, Lim KR, Lee CY, Park KH, Safavi KE, Fouad AF et al. Effects of removing residual peroxide and other oxygen radicals on the shear bond strength and failure modes at resin-tooth interface after tooth bleaching. Am J Dent 2004;17(4):267-70.

28. Schmidlin PR, Zimmermann J, Bindl A. Effect of ozone on enamel and dentin bond strength. J Adhes Dent. 2005;7(1):29-32.

29. Whang $H$, Shin D. Effects of applying antioxidants on bond strength of bleached bovine dentin. 2015;40(1):37. http://dx.doi.org/10.5395/ rde.2015.40.1.37

30. Freire A, Durski MT, Ingberman M, Nakao LS, Souza EM, Vieira S. Assessing the use of 35 percent sodium ascorbate for removal of residual hydrogen peroxide after in-office tooth bleaching. J Am Dent Assoc. 2011; 142:836-41. https://doi.org/10.14219/jada.archive.2011.0273

31. Hansen JR, Frick KJ, Walker MP. Effect of 35\% Sodium Ascorbate Treatment on Microtensile Bond Strength after Nonvital Bleaching. JOE; 2014;40(10). https://doi.org/10.1016/j.joen.2014.06.001

32. Kimyai $\mathrm{S}$, Valizadeh $\mathrm{H}$. The Effect of Hydrogel and Solution of Sodium Ascorbate on Bond Strength in Bleached Enamel. Operative Dentistry. 2006;31(4):496-9. https://doi.org/10.2341/05-85

33. Türkün M, Celik EU, Kaya $A D$, Arici $M$. Can the hidrogel form of sodium ascorbate be used to reverse compromised bond strength after bleaching? J Adhes Dent 2009;11(1):35-40.

34. Güler E, Gönülol N, Özyilmaz OY, Yücel AC. Effect of sodium ascorbate on the bond strength of silorane and methacrylate composites after vita bleaching. Braz Oral Res. 2013;27(4):299-304.

35. Sasaki RT, Flório FM, Basting RT. Effect of $10 \%$ sodium ascorbate and $10 \%$ alpha-tocopherol in different formulations on the shear bond strength of enamel and dentin submitted to a home use bleaching treatment. Oper Dent. 2009;34(6):746-52. https://doi.org/10.2341/09-029-L

36. Han Y, Mo S, Jiang L, Zhu Y. Effects of antioxidants on the microleakage of composite resin restorations after external tooth bleaching. European Journal of Dentistry. 2014;8(2).

37. Dabas D, Patil AC, Uppin VM. Evaluation of the effect of concentration and duration of application of sodium ascorbate hydrogel on the bond strength of composite resin to bleached enamel. J Conserv Dent 2011; 14(4):356-60. https://doi.org/10.4103/0972-0707.87197 